\author{
Review Article \\ www.ijrap.net
}

\title{
A COMPREHENSIVE STUDY OF PUSHKARMULA (INULA RACEMOSA HOOK. F.) IN BRIHATTRAYI AND LAGUTTRAYI: A REVIEW
}

Vashisht Kiran $^{1 *}$, Singh D. C. ${ }^{2}$, Thakur Vivek ${ }^{3}$

${ }^{1}$ Ph.D. Scholar, Department of Dravyaguna, Faculty of Ayurveda, I.M.S, B.H.U, Varanasi, India

${ }^{2}$ Professor and HOD, Department of Dravyaguna, Uttarakhand Ayurved University, Rishikul Campus, Haridwar, Uttarakhand, India

${ }^{3}$ M.D. Scholar, Department of Rasa-Shastra \& Bhaishjya Kalpana, Uttarakhand Ayurved University, Rishikul Campus, Haridwar. Uttarakhand, India

Received on: 20/06/16 Revised on: 25/07/16 Accepted on: 08/08/16

*Corresponding author

E-mail: vashishtkiran312@yahoo.com

DOI: $10.7897 / 2277-4343.074151$

\section{ABSTRACT}

Brihattrayi (Greater triad) and Laghuttrayi (Lesser triad) are excellent, highly esteemed and extensively used sources of Ayurvedic knowledge. Brihattrayi comprises Charaka Samhita, Sushruta Samhita and Astanga Hridaya and Laghuttrayi comprises Madhava nidana, Sharangdhar samhita and Bhava prakasha. There is no reference of Pushkarmula in Vedas, but in Samhita it is use in Swasa \& other allied disease and it is stated that Pushkarmula is best medicine for Hikka, Kasa, Swasa and Parshwashula and also has been included in different groups of drug which are effective in Swasa roga. This article reviews the various references of Pushkarmula in Brihattrayi and Laghuttrayi regarding its different formulations and its prime therapeutic indications.

Keywords: Brihattrayi kala, Laghuttrayi, Pushkarmula (Inula racemosa Hook F.)

\section{INTRODUCTION}

Drug consists of the dried root Inula racemosa (Hook f.) family Asteraceae. It is a stout herb or undershrub, upto 1.5 meters tall, distributed in North-western Himalayas from Kashmir eastwards, at an altitude between 1600-4200 meters and also cultivated in Himachal Pradesh, Uttarakhanda and Sikkim. ${ }^{1}$

Inula racemosa (Hook f.) is a tall, stout perennial herb. Its stem erect, $.03 \mathrm{~m}-1.5 \mathrm{~m}$ high. It has simple, alternate, opposite or whorled leaves. Leaves are membranous, irregularly toothed; basal one very large, $0.6-1.2 \mathrm{~m}$ long, triangular, with a long lobately winged stalk. Stem leaves are smaller. Flowers heads, stalk less, hard, rounded, $3.8-5 \mathrm{~cm}$. dia., $2-5$ forming axillary and terminal clusters. Bracts surrounding the heads many, ovatelancelate, long, pointed, rigid, bent back, hairless. Corolla $2 \mathrm{~cm}$. long, tubular, dark blue-purple or almost black. Stamens free. Another tails fringed. Achene- $3 \mathrm{~mm}$. long curved and compressed. Pappus hairs $1.7 \mathrm{~cm}$ long, brown, all feathery. Fruit achene, up to $8 \mathrm{~mm}$ long, compressed, curved, tip narrowed, with $1 \mathrm{rib}$ on each face, top contracted, cupped. Root is stout, up to $60 \mathrm{~cm}$ long brownish with longitudinal streaks and furrows with reticulate surface, having characteristic odor. ${ }^{2}$

It act as Vataghna, Kaphaghna, Jwaraghna, Shothaghna, Ruchya, Swasaghna, Anulomana, Uttejaka, Vranaropana, Vamaka, Deepana, Paachana and Parshvashulahara. ${ }^{3}$

\section{Pushkarmula (Inula racemosa Hook F.) in Brihattrayi}

Charaka Samhita: - $\left(1000 \text { B.C. }-4^{\text {th }} \text { A.D. }\right)^{4}$

It is first of three most important treatise of Ayurveda, which are jointly known as Brihattrayi. In "Charaka Samhita" Pushkarmula has been described in Hikkanighrahana Mahakashaya and Swashhara Mahakashaya. In Agraya prakarana Charaka has mentioned Pushkarmula best for Hikka, Kasa, Swasa and Parshwashula. This is used as an ingredient of many preparations for external and internal medication.

Table 1: Pushkarmula as an ingredient of many preparations in Charaka Samhita

\begin{tabular}{|c|c|c|c|}
\hline S. No. & Name of preparations/ Gana / Group of Drugs & Indication & Reference \\
\hline 1. & Hikka Nigrahana Mahakasaya & Hikka Prashaman & C.S.Su. 4/ 30 \\
\hline 2. & Swasahar mahakasaya & Swasa Chikitsa & C.S.Su. 4/ 37 \\
\hline 3. & Pradhana aushadhi dravya ke hitkar ahitkar karma & Swasa-kasa-hikka- parsva-shula Chikitsa & C.S.Chi. 3/ 211 \\
\hline 4. & Shatyadi Varga & Parsva-shula, Swasa & C.S.Chi. 2/ 225 \\
\hline 5. & Baladi Ghrita & Shira-shula Chikitsa & C.S.Chi. 3/ 267 \\
\hline 6. & Agurvadi Taila & Sheet-jwara Chikitsa & C.S.Chi. 6/ 41 \\
\hline 7. & Lodhrasava & Prameha Chikitsa & C.S.Chi. 8/ 101 \\
\hline 8. & Durvadya Ghrita & Rajyakshma,Shirahshula & C.S.Chi. 17/ 123 \\
\hline 9. & Yakshma nashak Ghrit & Hikka. Swasa & C.S.Chi. 18/ 53 \\
\hline 10. & Shatyadi Churna & Kasa & C.S.Chi. 26/ 22 \\
\hline 11. & Chitrakadi Leha & Pliha, Udara roga & C.S.Chi. 26/ 97 \\
\hline 12. & Hingugranthyadi Churna & Kapha janya Hridaya roga & \\
\hline 13. & Katphaldi Kwath & &
\end{tabular}


Sushruta Samhita: - (1000 B.C.-2 ${ }^{\text {th }}$ A.D. $)^{5}$

Sushruta Samhita authorised by Vriddha Sushruta is the next most important treatise of Ayurveda, Sushruta was basically a surgeon, yet he has discussed etiology, diagnosis and treatment of diseases in a very scientific way in his treatise.

He also recognized Pushkarmula as an important drug for clinical practice. As an ingredient of specific formulation or as a member of various groups of drugs in Sushruta Samhita are cited below:

Table 2: Pushkarmula as an ingredient of many preparations in Sushruta Samhita

\begin{tabular}{|c|c|c|c|}
\hline S. No. & Name of preparations/ Gana / Group of Drugs & Indication & Reference \\
\hline 1. & Puskar guna & Rakta pitta nashak & S. S. Su. 46/173 \\
\hline 2. & Aptantraka nasak ghrita & Maha vata vyadhi & S. S. Chi. 5/21 \\
\hline 3. & Hinguyadi churna & -do- & S. S. Chi. 5/28 \\
\hline 4. & Dhanvantari ghrita & Prameha pidika & S. S. Chi $12 / 5$ \\
\hline 5. & Kalshisadi ghrita & Jeerna jwara & S. U. 39/ 225 \\
\hline 6. & Purshwashula & S. U. 42/ 120 \\
\hline 7. & Talishyadi churna & Shwasa & S. U. 51/27 \\
\hline 8. & Devdarvyadi kwath & Udavarta chikista & S. U. 55/ 45 \\
\hline 9. & Panchgavya ghrita & apasmaarnasak & S. U. 61/35 \\
\hline
\end{tabular}

\section{Ashtanga Hridaya: $\left(7^{\text {th }} \text { A.D. }\right)^{6}$}

This is third most important treatise among Brihattrayi, written by Acharya Vagbhata. Subjects are very precisely collected and described in this book. Vagabhata followed Charaka and Sushruta regarding importance and use of Pushkarmula. References of Pushkarmula traced in this treatise are mentioned below:-

Table 3: Pushkarmula as an ingredient of many preparations in Ashtanga Hridaya

\begin{tabular}{|c|c|c|c|}
\hline S. No. & Name of preparations/ Gana / Group of Drugs & Indication & Reference \\
\hline 1. & Vata Kapha Jwara Nasaka & Vata Kapha Jwara Shamana & A.H.Chi.1/166 \\
\hline 2. & Agastyaharitaki & Kasha & A.H.Chi.3/128 \\
\hline 3. & Dashmula Ghrita & -do- & A.H.Chi.3/20 \\
\hline 4. & Kasa Nashaka Peya & -do- & A.H.Chi. 3/31 \\
\hline 5. & Kasa Nashaka Leha & -do- & A.H.Chi. 3/53 \\
\hline 6. & Guduchyadi Yoga & -do- & A.H.Chi. 3/158 $6 / 30$ \\
\hline 7. & Chavyadi Ghrita & Hridya roga Nashaka & A.H.Chi. 14/31 \\
\hline 8. & Pushkarmuladi Ghrita & Gulma Nashaka & A.H.Chi. 14/49 \\
\hline 9. & Hinguvadi Churna & Daha shula Nashaka & A.H.U. 7/20 \\
\hline 10. & Daha Shula Nasaka Kwath & Parshwashula hara & A.H.U. 40/56 \\
\hline 11. & Maha Panchgavya Ghrita & Visha Nashaka & A.H.U. 36/56 \\
\hline 12. & Roga Shamaka & &
\end{tabular}

\section{Pushkarmula (Inula racemosa (Hook F.) in Laghuttrayi}

Madhava Nidana $\left(7^{\text {th }} \text { A.D. }\right)^{7}$

It is first of three most important treatise of Ayurveda, which are jointly known as Laghuttrayi. In Madhava Nidana Pushkarmula has not been described.

Sharangdhara Samhita: - $\left(13^{\text {th }} \text { A.D. }\right)^{8}$

It is second of three most important treatise of Ayurveda, which are jointly known as Laghuttrayi. In this Samhita Pushkarmula has been described in many diseases as an ingredient of different preparation. The detail descriptions are cited below:-

Table 4: Pushkarmula as an ingredient of many preparations in Sharangdhara Samhita

\begin{tabular}{|l|c|c|c|}
\hline S. No. & Name of preparation/ Gana / Group of Drugs & Indication & Reference \\
\hline 1. & Brihata kshudrayadi kwatha & Vishama jwara & Sa.S.M.2/52 \\
\hline 2. & Kshudrayadi kwatha & Swasa, Kasa & Sa.S.M.2/83 \\
\hline 3. & Gridrasi nasak kwatha & Gridrashi & Sa.S.M.2/86 \\
\hline 4. & Shudarshana churna & Sarva jwara nasaka & Sa.S.M.M.6/39 \\
\hline 5. & Katphaladi churna & Jwara, Swasa, Kasa & Sa.S.M.6/41 \\
\hline 6. & Brihata Katphaladi churna & -do- & Sa.S.M.6/43 \\
\hline 7. & Dvitiya katphaladi churna & Pancha Kasa & Sa.S.M.6/45 \\
\hline 8. & Yavaksharayadi churna & Jwara, kasa & Sa.S.M.6/83-91 \\
\hline 9. & Narayana churna & Yakrita, pliha & Sa.S.M.6/101 \\
\hline 10. & Lavangtriyadya churna & Shula & Sa.S.M.6/107 \\
\hline 11. & Tumbruyadi churna & Udar shula, Vata roga & Sa.S.M.6/121 \\
\hline 12. & Hinguwadi churna & &
\end{tabular}




\section{Bhavaprakasha Chikitsa: - $\left(16^{\text {th }} \text { A.D. }\right)^{9}$}

This is third most important treatise among Laghuttrayi, written by Acharya Bhava Mishra. In Bhava prakasha Pushkaramula is mentioned under Haritakyadi Varga with the following synonyms such as - Pushkara, Padmapatra and Kashmira Kustha. In Bhava prakasha Pushkaramula has been described in form of different preparations as a ingredient which are indicated in various diseases mainly in Vata Kapha Jwara, Shotha, Aruchi, Swasa and Parshwashula etc. are cited below:-

Table 5: Pushkarmula as an ingredient of many preparations in Bhavaprakasha

\begin{tabular}{|l|c|c|c|}
\hline S. No. & Name of preparation/ Gana / Group of Drugs & Indication & Reference \\
\hline 1. & Sudarshna Churna & Vishama Jwara & B.P.Chi.1/126 \\
\hline 2. & Chaturbhadraka Aveleha & Jwarajanya Kasa, Swasa & B.P.Chi.1/379 \\
\hline 3. & Astanga Aveleha & Kaphaja Jwara & B.P.Chi.1/380 \\
\hline 4. & Brihata Pippalayadi Kwatha & Pittaja Jwara & B.P.Chi.1/408 \\
\hline 5. & Astanga Aveleha & Sannipataja Jwara & B.P.Chi.1/559 \\
\hline 6. & Astadasangha Kwatha & Jwara & B.P.Chi.1/761 \\
\hline 7. & PadamkadiTaila & Jwara, Swasa & B.P.Chi.1/844 \\
\hline 8. & Dasanga Taila & Swasa & B.P.Chi.14/36-38 \\
\hline 9. & Swasa roga nasaka yoga & B.P.Chi.19/45 \\
\hline 10. & Tandra nasaka yoga & Vata Vyadhi & B.P.Chi.24/111 \\
\hline 11. & Hinguvadi Churna & Pakshaghata, Urustambha & B.P.Chi.25/47 \\
\hline 12. & Maha Saindhavadi Taila & Aamavata & B.P.Chi.26/31 \\
\hline 13. & Hinguvadi Churna & -do- & B.P.Chi.26/117 \\
\hline 14. & Brihata Saindhavadi Churna & Shula, Gulma & B.P.Chi.30/45 \\
\hline 15. & Tumbarauadi Churna & Gulma & B.P.Chi.32/30 \\
\hline 16. & Hinguvadi Churna & Hridaya roga & B.P.Chi.34/12 \\
\hline 17. & Hridaya roga nashaka & Ashmari chikitsa & B.P.Chi.37/95 \\
\hline 18. & Punarnavadhya Taila & Mandagni & B.P.Chi.41/50 \\
\hline 19. & Narayana Churna & &
\end{tabular}

\section{DISCUSSION}

Inula racemosa (Hook f.) is the original source of Pushkarmula. There is no reference of Pushkarmula in Vedas, but in Samhita it is use in Swasa \& other allied disease and it is stated that Pushkarmula is best medicine for Hikka, Kasa, Swasa and Parshwashula and also has been included in different groups of drug which are effective in Swasa roga. In classics, Pushkarmula has been mentioned in those medications useful in respiratory diseases as a lepa/pralepa/aveleha. The Asteraceae family comprises approximately 1000 genera and 30,000 species, distributed throughout the globe, of which, approximately 177 genera and 1052 species are found in India. ${ }^{10}$ Inula racemosa is a critically endangered species due to the fragile nature of its habitat, and its exploitation due to commercial medicinal properties. The species is facing the onslaught of indiscriminate over exploitation, habitat destruction and competition. The populations of the species in the entire north western Himalayan range are witnessing a speedy decline in density, dwindling both in size and number. ${ }^{11}$

\section{CONCLUSION}

The present review on Pushkarmula of both Brihattrayi and Laghuttrayi can be useful to know about different formulations of Pushkarmula. By this way we can use Pushkarmula in the treatment of different diseases. Most of the Samhita Grantha have mentioned it in the treatment of Kasa, Swasa (respiratory disease), Hridaya roga, Vata vyadhi (epilepsy), Jwara (fever) and Vrana prasadana (wound healing). It is use as Rasayana also. In this regard, further studies need to carry out to explore Pushkarmula for its therapeutics potential in preventing and treating diseases.

\section{REFERENCES}

1. Quality standard of Indian Medicinal Plant, Indian Council of Medicinal Research, Vol. IV. 2004

2. Kirtikar K.R. \& Basu B.D. Indian Medicinal Plants, Volume II. $12^{\text {th }}$ ed. International Book Distributors, Dehradun; 2006.

3. Lucas D.S. Dravyaguna Vigyana, Vol.III. Chaukhambha Vishvabharati, Varanasi; 2010.

4. Shastri Gorakhnath, Agnivesh, Charaka Samhita, part I and II. 'Vidhyotani' hindi commentary, Chaukhamba Bharti Academy, Varanasi: 2010

5. Shastri Ambikadutta, Sushruta Samhita, partI and II. 'Ayurveda Tattva Sandipika, Chaukhamba Sanskrit Sansthan, Varanasi; 2010

6. Gupta, Kaviraja Atrideva, Astanga Hridaya of Vagbhatta, Vidyotini Hindi commentary, Chaukambha Sanskrit Sansthan, Varanasi; 2011

7. Shastri Sudarshana, Mahava Nidana. 'Madhikosh Vykhya' Chaukhamba prakashana, Varanasi; 2012

8. Shailaja Srivastava, Acharya Sharangdhara, Sharngadhara Samhita. Jivanprada Hindi commentary, Chaukhambha orientalia, Varanasi; 2011

9. Prof.K.C.Chunekar, Mishra Bhava, Bhava-Prakasha Samhita and Nighantu, Comm. Chaukhambha bharati academy, Varanasi; 2011

10. Rao K.S., Mishra SH, Hepatoprotective activity of Inula racemosa roots Fitoterapia; 1997

11. Parvaiz AW, Kursheed AG, Irshad AN, Wafai BA. Phenological episode and reproductive strategies of Inula racemosa (Asteraceae) - A critically endangered medicinal herb of western Himalayas. 2006

\section{Cite this article as:}

Vashisht Kiran, Singh D. C., Thakur Vivek. A comprehensive study of Pushkarmula (Inula racemosa Hook. F.) in Brihattrayi and Laguttrayi: A review. Int. J. Res. Ayurveda Pharm. Jul Aug 2016;7(Suppl 3):27-29 http://dx.doi.org/10.7897/22774343.074151 